\title{
Pengaruh Riwayat Pelatihan Terhadap Kreativitas Guru Dalam Merancang Media Pembelajaran
}

\author{
Sumiatun \\ PG-PAUD STKIP Modern Ngawi \\ Jl. Ir Soekarno (Ring Road Barat) Kabupaten Ngawi \\ sumiatun.sumiatun@gmail.com
}

\begin{abstract}
Abstrak
Riwayat pelatihan yang diikuti oleh pendidik mempengaruhi kreativitas dalam merancang media pembelajaran.Penelitian ini bertujuan untuk mengetahui apakah pelatihan-pelatihan yang pernah diikuti oleh pendidik dapat mempengaruhi kreativitas dalam merancang media pembelajaran yang ada di Kecamatan Ngraho Kabupaten Bojonegoro.penelitian ini menggunakan metode Kuantitatif dengan jumlah sampel 30 orang pendidik.Pengumpulan data yang dilakukan dalam penelitian ini adalah dengan angket yang diperoleh dari kuisioner kepada responden (pendidik di Kecamatan Ngraho Kabupaten Bojonegoro). Hasil dari penelitian ini adalah menunjukkan bahwa riwayat pelatihan mempengaruhi kreatiivitas dalam merancang media pembelajaran di Kecamatan Ngraho Kabupaten Bojonegoro termasuk dalam kategori baik dengan hasil presentase $87 \%$ dari 30 orang pendidik.
\end{abstract}

Kata Kunci: kreativitas, riwayat, pelatihan

\section{PENDAHULUAN}

Memberikan batasan sebagai berikut, kreativitas adalah kemampuan untuk membuat kombinasi baru, berdasarkan data, informasi, atau unsur-unsur yang ada (Utami, 2002). Dalam hal ini, Munandar mengartikan bahwa kreativitas sesungguhnya tidak perlu menciptakan hal-hal yang baru, tetapi merupakan gabungan (kombinasi) dari halhal yang sudah ada sebelumnya.Sedangkan yang dimaksud dengan data, informasi, atau unsur-unsur yang ada, dalam arti sudah ada atau sudah dikenal sebelumnya, adalah semua pengalaman yang telah diperoleh seorang selama hidupnya termasuk segala pengetahuan yang pernah diperolehnya. Oleh karena itu, semua pengalaman memungkinkan seseorang mencipta, yaitu dengan menggabung (mengkombinasikan) unsur-unsurnya menjadi sesuatu yang baru. Kreativitas (berpikir kreatif atau berpikir divergen) adalah kemampuan berkreasi berdasarkan data atau informasi yang tersedia dalam menemukan banyak kemungkinan jawaban terhadap suatu masalah, dimana penekanannya adalah pada kuantitas, ketepatgunaan dan keragaman jawaban. Jawaban-jawaban yang diberikan harus sesuai dengan masalah yang dihadapi dengan memperhatikan kualitas dan mutu 
dari jawaban tersebut. Berpikir kreatif dalam menjawab segala masalah adalah dengan menunjukkan kelancaran berpikir (dapat memberikan banyak jawaban), menunjukkan keluwesan dalam berpikir (fleksibilitas), memberikan jawaban yang bervariasi, dan melihat suatu masalah dari berbagai sudut tinjauan.Secara operasional kreativitas dapat dirumuskan sebagai "kemampuan yang mencerminkan kelancaran, keluwesan (fleksibilitas), dan orisinalias dalam berpikir, serta kemampuan untuk mengelaborasi (mengembangkan, memperkaya, memperinci) suatu gagasan.

Pengalaman atau pengtahuan seseorang dari lingkungan sekitar yang diterima seseorang untuk mengkombinasikan sesuatu hal yang memilki nilai guna. Jadi dapat diartrikan bahwa seseorang yang kreatif memiliki daya cipta atau intelektual yang tinggi yang mana menggabungkkan unsur yang sudah ada dengan penciptaan hal yang baru hingga menghasilkan suatu hal yang baru menjadi lebih terlihat keindahannya serta nilai gunanya bahkan membuat ketertarikan tersendiri bagi penglihatnya.

Seseorang yang memliki kreativitas dapat memiliki kemampuan dan ketrampilan dalam menyelesaikan masalah dalam arti memiliki ide atau metode bagaimana cara menyelesaikan masalah dengan caranya sendiri. Menurut (E. B. Hurlock, 1995) mendifinsikan kreativitas sebagai kemampuan untuk memproduksi komposisi dan gagasan-gagasan baru yang dapat berwujud kreativitas imanjenatif atau sintesis yang mungkin melibatkan pembentukan pola-pola baru dan kombinasi dari pengalaman masa lalu yang dihubungkan dengan yang sudah ada pada situasi sekarang. Kreativitas juga tidak selalu menghasilkan sesuatu yang dapat diamati dan . Hal ini hampir seruopa dengan pendapat Utami Munandar yang menggebungkan hal yang sudah ada dengan suatu hal yang baru dikombinasi dan mengikuti zaman diera sekarang ini sehingga khalayak ramai tertarik dengan produk yang dihasilkan. Dari uraian diatas dapat disimpulkan bahwa kreativitas merupakan kemampuan seseorang untuk melahirkan sesuatu yang baru, baik berupa gagasan maupun karya nyata, baik dalam bentuk karya baru maupun kombinasi dari hal-hal yang sudah ada, yang semuanya itu relatif berbeda dengan apa yang telah ada sebelumnya,pemikiran ini didapat dari gagasan sendiri atau yang disebut dengan orisinil.

Kreativitas dapat mempengaruhi kehidupan seseorang, misalnya dengan kreativitas seseorang dapat mempengaruhi ekonomi seseorang. Dengan krreativitas juga seseorang dapat menciptkan suatu hal bahkan penciptaan sesuatu hal yang berbeda dengan orang lain yang menarik perhatian orang banyak.Kreativitas juga dapat mempengaruhi intelektual seseorang yang dapat meengembangkan pola berfikir seseorang dapat menyelesaikan masalahnya dengan ide-ide cara mereka sendiri .Terutama bagi pendidik kreativitas sangat penting untuk mengembangkan pengetahuan dan keterampilan saat proses kegiatan belajar mengajar. Sebagai pendidik tentunya terkadang merasa bingung bagaimana cara menyampaikan materi dengan mudah dapat diterima oleh peserta didik,dan pendidik harus mempelajarai tentang bagaimana cara membuat peserta didik merasa aman,nyaman dan menyenangkan ketika proses belajar mengajar berlangsung. Salah satunya dengan menggunakan media pembelajaran dapat mempermudah pendidik dalam menyampaikan materi yang akan disampaikan. Tetapi sebelum menggunkan media pembelajaran pendidik harus 
merencanakan atau merancang dahulu media yang akan digunakan apakah media yang akan digunakan sesuai dengan kriteria peserta didik yang diampu.

Dalam dunia pendidikan tentunya tak asing lagi ketika mendengar pelatihan. Pelatihan dilakukan dengan tujuan untuk meningktakan pengertahuan serta keteranpilan seseorang. Pelatihan sangat penting bagi pendidik guna meningkatkan pengetahuan, kemampuan dan terampilan seorang pendidik untuk menghadapi berbagai masalah yang ada serta dapat memotivasi diri seseorang. Sebaliknya juga motivasi yang tinggi memiliki hasil yang positif terhadap hasil pelatihan (Laksono, 2018)

\section{METODE}

Metode yang digunakan dalam penelitian ini adalah kuantitatif denganstatistik inferensial.Statistik Inferensial adalah teknik statistik yang digunakan untuk menganalisis data sampel dan hasilnya diberlakukan untuk populasi. Statistik ini akan cocok digunakan bila sampel diambil dari populasi yang jelas, dan teknik pengambilan sampel dari populasi itu dilakukan secara random. Statistik ini disebut statistik probabilitas, karena kesimpulan yang diberlakukan untuk populasi berdasarkan data sampel itu kebenarannya bersifat peluang (probability). Suatu kesimpulan dari data sampel yang akan diberlakukan untuk populasi itu mempunyai peluang kesalahan dan kebenaran (kepercayaan) yang dinyatakan dalam bentuk presentase. Peluang kesalahan dan kepercayaan ini disebut dengan taraf signifikansi (Sugiono, 2016).

Penelitian ini dilakukan di Desa Klempun Kecamatan Ngraho Kabupaten Bojonegoro,dan sasaran pada penelitian ini adalah 30 orang dari pendidik yang ada dikecamatan Ngraho Kabupaten Bojonegoro.Penelitian ini menggunakan pendekatan kuantitatif dengan harapan hasil informasi yang didapatkan dapat diberlakukan secara umum yakni populasi penelitian (Sugiono, 2016), dengan variable $\mathrm{X}$ sebagai kreativitas dan Y sebagai riwayat Pelatihan yang pernah diikuti oleh pendidik. Teknik pengumpulan data yang digunakan pada penelitian ini adalah angket. Pengumpulan data Angket adalah teknik pengumpulan data yang dilakukan dengan cara memberi seperagkat pertanyaan tertulis kepada responden untuk dijawabnya(Sugiono, 2016).

\section{HASIL DAN PEMBAHASAN \\ Hasil}

Berdasarkan penelitian yang telah dilakukan bahwa rata-rata $23 \%$ dari 30 orang pendidik di Kecamatan Ngraho Kabupaten Bojonegoro berusia Kurang dari 30 tahun dan usia kurang dari 25 tahun berjumlah 6 orang,lebih dari 25 tahun berjumlah 5 orang,30 tahun berjumlah 5 orang,40 tahun berjumlah 5 orang serta usia lebih dari 40 tahun berjumlah 3 orang.

Latar pendidikan rata-rata berada pada $63 \%$ dari 30 orang yakni dengan Lulusan SMA Sederajad,sedangkan SMP sederajat berjumlah 0,Lulus S1 Linier berjumlah 6 orang dang lainnya berjumlah 5 orang. Dengan latar belakang pendidikan yang dimiliki pendidik dapat mempengaruhi kemampuan kreativitas dalam merancang media pembelajaran atau APE.Karena semakin tinggi latar pendidikan seorang pendidik maka semakin luas juga pengetahuan dan pengalaman yang dimilikinya.

Berdasarkan penelitian yang telah dilakukan menunjukkan bahwa $43 \%$ dari 30 pendidik di Kecamatan Ngraho Kabupaten Bojonegoro rata-rata memiliki masa kerja 
lebih dari 6 tahun sedangkankan dengan masa kerja kurang lebih dari 1 tahun berjumlah 0,1-3 tahun berjumlah 5 orang dan 4-6 tahun berjumlah 12 orang .Pengalaman bekerja seorang pendidik juga mempengaruhi kreativitas seorang pendidik dalam merancang media pembelajaran.Semakin lama pengalaman bekerja seseorang maka semakin luas juga pengalaman dan pengetahuan mengajar seorang pendidik.

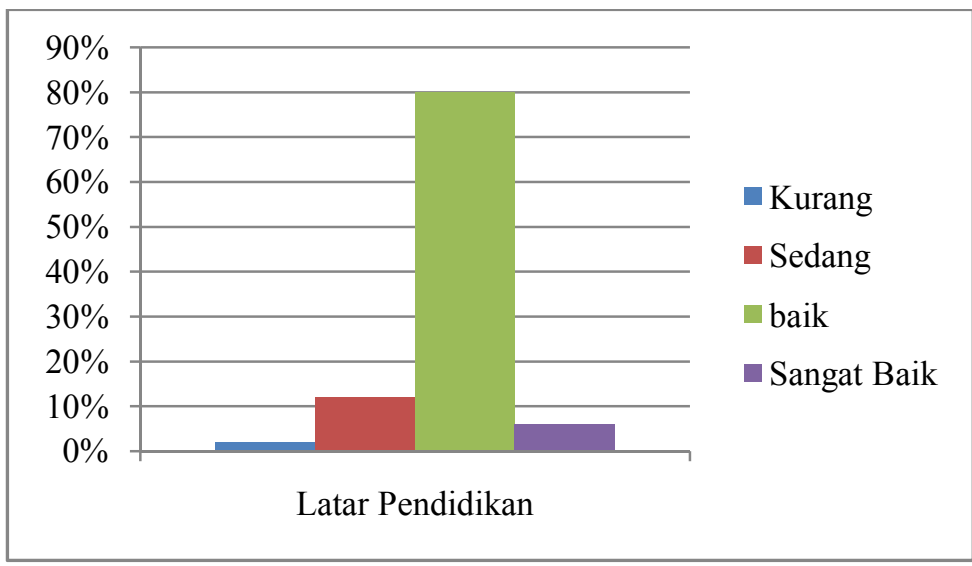

\section{Kreativitas}

Berdasarkan penelitian yang telah dilakukan menunujukkan bahwa pendidik di Kecamatan Ngraho Kabupaten Bojonegoro rata-rata memiliki tingkat kreativitas $87 \%$ dari 30 orang pendidik dan termasuk dalam kategori Baik.Dengan kreativitas yang diimiliki pendidik, perancangan media pembelajaran selalu diperbarui dengan ideide atau gagasan yang dimilkinya. Sehingga kreativitas yang dimiliki seorang pendidik mempengaruhi kreativitas dalam merancang media pembelajaran .Dengan kreativitas pendidik juga dapat memecahkan masalah yang akan dihadapi dengan menentukkan cara, ide atau gagasan sebagai solusinya.

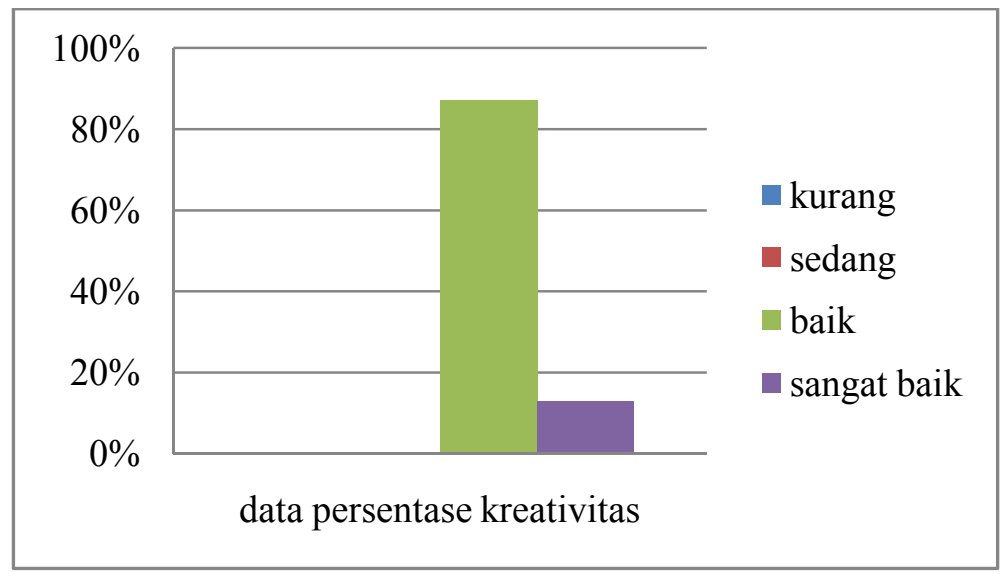

\section{Riwayat Pelatihan}

Berdasarkan penelitian yang telah dilakukan menunjukkan bahwa rata-rata $80 \%$ dari 30 pendidik di Kecamatan Ngraho
Kabupaten Bojonegoro yang telah diinterview pengalaman pelatihan yang pernah diikuti berada dalam kategori Baik.jadi dapat disimpulkan bahwa 
pelatihan-pelatihan yang pernah diikuti pelatihan-pelatihan yang pernah diikuti pendidik mempengaruhi kreativitas dalam pendidik dapat meningkatkan kemampuan merancang media pembelajaran.Dengan dan keterampilan para pendidik.

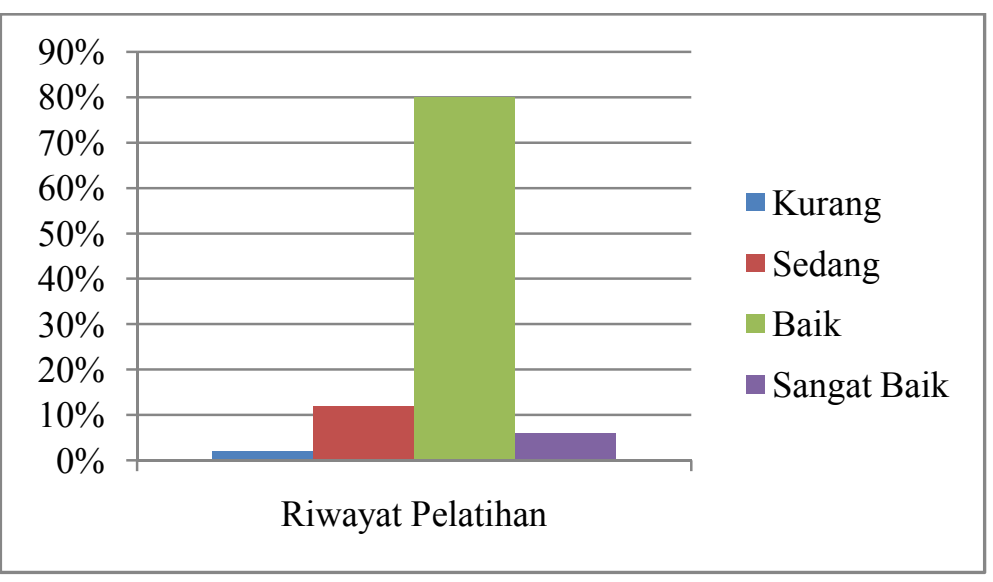

Pengaruh Riwayat Pelatihan Terhadap Kreativitas Dalam Merancang Media Pembelajaran (APE)

\begin{tabular}{|l|l|l|l|l|l|}
\hline Model & Sum of Squares & df & Mean Square & F & Sig. \\
\hline 1 & 46.080 & 1 & $\begin{array}{l}46.080 \\
4.432\end{array}$ & 10.398 & $.003^{\mathrm{b}}$ \\
Regression & 124.087 & 28 & & & \\
\hline $\begin{array}{l}\text { Residual } \\
\text { Total }\end{array}$ & 170.167 & 29 & & & \\
\hline
\end{tabular}

a. Dependent Variable: Kreativitas

b. Predictors: (Constant), Riwayat Pendidikan

Dari Hasil penelitian ini diperoleh regresi pengaruh riwayat pelatihan terhadap kreativitas dalam merancang media pembelajaran atau APE menunjukkan hasil sebesar 4.432 jadi dapat dikatakan layak atau berpengaruh antara riwayat pelatihan terhadap kreativitas dalam meracang media pembelajaran.Berdasarkan analisis data di atas dapat diketahui juga bahwa terdapat pengaruh yang kuat dan signifikan riwayat pelatihan dengan kreativitas dalam merancang media pembelajaran.

\section{Pembahasan}

Berdasarkan penelitian yang telah dilakukan bahwa rata-rata latar belakang pendidikan pendidik dikecamatan Ngraho
Kabupaten Bojonegoro lulusan SMA sederajat hal ini berpengaruh terhadap kemampuan dan keterampilan pendidik dalam dunia pendidikan. Salah satunya dalam hal merancang media pembelajaran. Dengan latar belakang pendidikan yang dimiliki pendidik dapat diartikan bahwa pada umumnya semakin tinggi latar belakang pendidikan orang tersebut maka pengetahuan dan pengalaman yang dimilikinya semakin luas. Hal ini sejalan dengan penelitian Pengaruh Latar Belakang Pendidikan Guru Terhadap Kompetensi Profesional Guru (Rismawati, 2020) yang menjelaskan bahwa untuk menunjang komptensi guru,harusnya guru memiliki keahlian khusus yang dipersiapkan oleh program pendidikan 
keahlian atau spesialisasi tetapi pada kenyataannya masih ada profesi guru yang tidak sesuai dengan latar belakang pendidikanya.Sehingga guru tersebut kukrang dapat berkompeten profesional dengan maksimal.Untuk memaksimalkan komptensi profesional guru yang latar belakang pendidikannya tidak sesuai harus diikutkan dalam program pendidikan dan pelatihan khusus.

\section{Kreativitas}

Berdasarkan penelitian yang telah dilakukan bahwa kreativitas pendidik di kecamatan Ngraho Kabupaten Bojonegoro menunjukkan dalam kategori baik.Dengan kreativitas yang dimiliki pendidik akan mempengaruhi kemampuan dan ketrampilan pendidik dalam dunia pendidikan salah satunya dalam hal merancang media pembelajaran (APE). Kreativitas yang dimiliki pendidik sebagian diperoleh dengan mengikuti pelatihan-pelatihan yang berhubungan dengan kompetisi yang harus dimiliki pendidik.Pendidik yang yang memiliki kreativitas pasti akan mempunyai ide-ide atau gagasan baru yang dapat menyelesaikan masalah yang dihadapinya. Hal ini berhubungan dengan penelitian Kreativitas Guru dalam mengembangkan Media Pembelajaran di TK B TKIT Raudhatul Jannah Bogor (Nurhanifah, 2018) yang menyatakan bahwa dampak dari kreativitas guru yang kreatif menjadikan anak antusias dalam mengikuti proses pembelajaran,membuat pembelajaran menjadi menyenangkan,anak sangat antusias terhadap pengunaan media yang dibuat guru pada saat pembelajaran.

\section{Pengaruh Riwayat Pelatihan Terhadap Kreativitas}

Berdasarkan penelitian yang telah dilakukan menunjukkan bahwa riwayat pelatihan yang pernah diikuti pendidik dalam kategori baik.Dapat diartikan bahwa riwayat pelatihan yang pernah diikuti pendidik mempengaruhi kreativitas pendidik dalam kemampuan dan keterampilan pendidik dalam mengajar. Hal ini sejalan dengan penelitian Pengaruh Pelatihan Keterampilan Kreatif Terhadap Kreativitas (Kurniati, 2014) yang menyatakan bahwa adanya perbedaan kreativitas yang signifikan sebelum dan sesudah pelatihan, pelatihan keterampilan kreatif efektif untuk meningkatkan kreativitas.

\section{PENUTUP \\ Kesimpulan}

Berdasarkan penelitian yang telah dilakukan bahwa secara umum dapat disimpulkan bahwa riwayat pelatihan mempengaruhi dalam kreativitas merancang media pembelajaran (APE) dikecamatan Ngraho Kabupaten Bojonegoro mayoritas $87 \%$ dari 30 orang pendidik dan dapat dikatakan dalam kategori baik.Pelatihanpelatihan yang pernah diikuti oleh pendidik mempengaruhi kreativitas dalam merancang media pembelajaran karena semakin sering mengikuti pelatihan maka semakin luas juga kemampuan, pengetahuan dan ketrampilan yang dimiliki.Sehingga dengan adanya pelatihan-pelatihan akan meninggkatan mutu dan kualitis pendidik dalam mengajar.

\section{Saran}

Berdasarkan penelitian yang sudah dilakasanakan maka peneliti dapat memberikan saran bahwa sebaikknya pendidik harus sering mengikuti pelatihanpelatihan yang ada terutama pelatihan dalam kreativitas dalam merancang media pembelajaran (APE),supaya mudah untuk menemukan solusi bagaimana untuk merancang dan membuat media pembelajaran (APE) yang sesuai dengan 
kriteria anak.Dan bukan hanya pelatihan dalam kreativitas saja tetapi juga pelatihanpelatihan yang dapat meningkatkan kopetisi pendidik.

\section{DAFTAR PUSTAKA}

E. B. Hurlock. (1995). Perkembangan Anak (I). Erlangga.

Kurniati, N. M. T. (2014). Pengaruh Pelatihan Ketrampllan Kreatif Terhadap Kreativitas - UG Repository [Universitas Gunadarma]. http://repository.gunadarma.ac.id/1124/

Laksono, B. A. (2018). The Effect Of SelfEfficacy On English Training Results. Jurnal Empowerment, 7(2), 39-46. $\mathrm{http}: / / \mathrm{e}-$ journal.stkipsiliwangi.ac.id/index.php/e mpowerment/article/view/907

Nurhanifah, S. (2018). Kreativitas Guru
Dalam Pengembangan Media Pembelajaran Di TK B TKIT Raudhatul Jannah Bogor Skripsi. Jakarta: Fakultas Ilmu Tarbiyah dan Keguruan UIN Syarif Hidayatullah.

Rismawati, W. C. (2020). Pengaruh Latar Belakang Pendidikan Guru Terhadap Kompetensi Profesional Guru. In widiacahyarismawati.blogs.uny.ac.id. http://widiacahyarismawati.blogs.uny.ac .id/wpcontent/uploads/sites/15332/2017/10/Pe ngaruh-Latar-Belakang-PendidikanGuru-Terhadap-KompetensiProfesional-Guru-1.pdf

Sugiono. (2016). Metode Penelitian Kuantitatif, Kualitatif, dan $R \& D$. Alfabeta.

Utami, M. (2002). Kreativitas dan keberbakatan. PT Gramedia Pustaka. 